\title{
Heterogeneity in top management teams and outward foreign direct investment: evidence from Chinese listed companies
}

\author{
Shuai Meng ${ }^{1}$, Jiayan Yan $^{2^{*}}$ (D) and Xuebing $\mathrm{CaO}^{3}$
}

\author{
* Correspondence: yanjiayan@ruc. \\ edu.cn \\ ${ }^{2}$ School of Business, Nanjing Audit \\ University, Nanjing 211815, China \\ Full list of author information is \\ available at the end of the article
}

\begin{abstract}
Drawing upon the knowledge-based view and team learning, we investigated how heterogeneity in top management teams (TMTs) in China influences global expansion strategies. Using panel data from Chinese listed firms from 2008 to 2014, we found that TMT functional background heterogeneity could positively affect firms' commitment to outward foreign direct investment (OFDI), as the diversification of TMT members can enrich the team's knowledge, facilitate efficient team learning, and enhance the decision-making capacity on overseas expansion. However, tenure heterogeneity may hinder knowledge acquisition and team learning among TMT members, hence undermining firms' OFDI commitment.

Keywords: Top management teams (TMTs), Tenure heterogeneity, Outward foreign direct investment (OFDI), Knowledge-based view (KBV), Team learning, Multinational enterprise (MNE)
\end{abstract}

\section{Introduction}

Firms from emerging economies have been expanding their businesses into overseas markets at an unprecedented pace in recent years, and this has attracted considerable research attention (Gaur et al. 2014). In 2017, for example, China became the third largest country in terms of outward foreign direct investment (OFDI) flows (UNCTAD 2018), while India has recorded a steady increase of OFDI for three decades, contributing to the country's impressive growth in global competitiveness (Pradhan 2017). Extant studies have investigated the antecedents of emerging economies' OFDI activities by examining key elements such as the country effect (Stoian and Mohr 2016; Yamakawa et al. 2008), the industry factor (Lu et al. 2011), and firm-level performance (Ramasamy et al. 2012). There have been studies probing the impact of board structures (Sanders and Carpenter 1998) and top executive compensation (Liu et al. 2014; Tihanyi et al. 2000) on international expansion, but so far the impact of top management team (TMT) heterogeneity, particularly the functional background and tenure heterogeneity, on emerging economy firms' OFDI is largely underexplored.

Situated at the center of the organization, the TMT is directly responsible for making or influencing strategic decisions such as international expansion (Athanassiou and Nigh 2000; Hambrick and Mason 1984). When facing international business opportunities, TMT characteristics such as overseas or export experience are instrumental for

(c) The Author(s). 2019 Open Access This article is distributed under the terms of the Creative Commons Attribution 4.0 International License (http://creativecommons.org/licenses/by/4.0/), which permits unrestricted use, distribution, and reproduction in any medium provided you give appropriate credit to the original author(s) and the source, provide a link to the Creative Commons license, and indicate if changes were made. 
forming a solid knowledge foundation and influencing internationalization decision-making (Hambrick et al. 1996; Li 2018). Yet the extent to which TMT functional background and tenure heterogeneity can influence firms' OFDI commitment is understudied. Especially when TMT members have different background, the heterogeneity can provide broad information and diverse skills that will benefit overseas venture decisions (Carpenter 2002); however, diversity may also lead to potential conflicts among team members (Amason and Sapienza 1997).

To make strategic decisions such as venturing abroad, TMTs need to have broad knowledge about the information on risk-taking, marketing behavior and business operations, all of which are the essential knowledge prepared for overseas activities. As the knowledge-based view (KBV) postulates, knowledge is the most important resource for firms' performance and competitive advantage (Gassmann and Keupp 2007; Grant 1996). For multinational enterprises (MNEs), effective acquisition of valuable knowledge and capabilities, through learning activities, is vital for improving global competitiveness in a dynamic international environment (Saarenketo et al. 2004). This process is heavily influenced by senior managers' background and experience, since, for example, the nationality diversity of top managers is one important source of their knowledge of and expertise on overseas markets (Nielsen 2010b). It is also related to the effectiveness of team performance and the outcome of management team learning (Bunderson and Sutcliffe 2003). Research has found that TMT heterogeneity exerts influence on international learning and knowledge acquisition actions (Ndofor et al. 2015); however, it is less clear on (1) the extent to which TMT heterogeneity can affect MNEs' internationalization commitments in emerging economies, and (2) which specific TMT characteristics are vital for influencing these firms' OFDI decisions.

The main purpose of the present study is to clarify the relationship between TMT functional background and tenure, and emerging economy firms' OFDI commitment. Building on the underlying research and theories associated with knowledge acquisition (e.g., KBV) and group learning (e.g., team learning perspective), we proposed that, whilst the overall level of diversity of the senior management team can facilitate firms' OFDI decisions, it is possible for different types of TMT heterogeneity to have different impacts on the internationalization commitment. Specifically, we chose senior management team members' functional background and tenure to assess the effect of TMT heterogeneity (Hambrick and Mason 1984; Ndofor et al. 2015). We chose functional heterogeneity and team tenure because first, cross-functional teams are prevalent in contemporary complex organizations (Boone and Hendriks 2009), and second, tenure is a critical conceptual footing among all demographic variables (Pfeffer 1985) and tenure heterogeneity can capture the level of team commitment diversity (Milliken and Martins 1996). To discuss OFDI decisions which rely highly on overseas knowledge and experience, we focused on some of the most important aspects of TMT characteristics, rather than the general ones, to depict the influence on OFDI decisions. Since international investment involves high level of risk and uncertainty, diversified functional background and team tenure will have a complicated impact on firms' OFDI commitment.

Given that much of the existing research is primarily based on the Western context, prior findings may not be entirely applicable for the case of emerging economy firms. Since firms' OFDI commitment embodies propensity, intensity, and institutional distance 
of overseas expansion (Deng et al. 2018), we suggested that functional background heterogeneity can bring in multilevel knowledge and broaden TMT understanding of international expansion, hence increasing the OFDI commitment of emerging economy firms. As tenure heterogeneity may generate more internal conflicts among TMT members and impede the process of knowledge acquisition and team learning (Carpenter 2002), it will likely decrease OFDI commitment. To test these propositions, we used a sample of 2636 publicly listed Chinese firms from panel data between 2008 and 2014; the results support our hypotheses.

This research makes three theoretical contributions. First, it advances our understanding of the role of TMT heterogeneity in overseas investment decisions by using KBV and team learning perspectives, enriching the upper echelons literature and the research on international expansion from emerging market economies. Second, the study brings new insight into the TMT heterogeneity research by identifying the heterogeneous roles of the executive management team and differentiating the effects of functional background and tenure among TMT members. Such a unique feature, as we proposed, can be termed as "multiplicity in TMT heterogeneity." Third, our research broadens the scope of learning theories to assess the effect of executives' team learning on internationalization. While extant research mainly focuses on organizational learning processes and individual learning outcomes (Casillas et al. 2009; de Clercq et al. 2012; Fernández-Mesa and Alegre 2015), our study pays attention to TMT learning, which is potentially a new analytical perspective for investigating OFDI commitment.

\section{Theoretical background}

\section{The knowledge-based view and team learning}

Although empirical research has surveyed the association between TMT heterogeneity and firm performance with reference to the upper echelons perspective (Hambrick et al. 1996; Murray 1989), there have been insufficient attempts to evaluate the relationship between executive management team diversity and emerging economy MNEs' intention to invest abroad. To address this research gap, we have drawn on the KBV and team learning, which can help assess the impact of TMT heterogeneity on OFDI decisions. Deriving from the resource-based view (RBV) theory, KBV advances the research frontier by shifting its focus from physical assets to intangible resources, particularly knowledge (Barney 1991; Gassmann and Keupp 2007; Grant 1996). Knowledge differs from other resources as it can be expressed in either explicit or tacit forms (Blome et al. 2014; Kaplan et al. 2001). Explicit knowledge, such as manuals, procedures, policies, production schedules, and market intelligence data, is easier to be codified and transferred (Anand et al. 2010), whereas tacit knowledge, rooted in one's experience, is implicit, subjective, and hard to conceptualize (Schoenherr et al. 2014). Tactic knowledge can be acquired and stored by individuals, and embedded in social and cultural contexts (Osterloh and Frey 2000). Unlike explicit knowledge that can be formulated, abstracted, and transferred across time and space independently, tactic knowledge needs close involvement and cooperation with knowing subjects (Lam 2000).

The KBV reiterates that as knowledge prevails, firms have the potential to create new value and competitive advantages (Grant 1996; Kogut and Zander 1992), with knowledge acquisition, integration, and transferring being essential organizational activities 
(Blome et al. 2014; Grant 1996). First of all, knowledge is a source of firms' long-term competitive advantage due to its invisibility, uniqueness, and applicability (Wiklund and Shepherd 2003). Additionally, as the accumulation, articulation, codification, and creation of knowledge are flexible in supporting dynamic capability development (Kogut and Zander 1992; Villar et al. 2014), firms that utilize knowledge well can get better prepared for making changes and avoiding rigidities (Easterby-Smith and Prieto 2008). Moreover, knowledge can help firms perceive new business potentials and opportunities in response to environmental changes (Lejpras 2015).

Research has further suggested that knowledge and organizational learning have become major contributors to firms' internationalization success (Villar et al. 2014). That is, organizational learning is an effective tactic for achieving market performance, gaining competitive advantages, and upgrading corporate strategies (Crossan et al. 1999; Duffield and Whitty 2015). Being a multilevel process, organizational learning entails activities at individual, team, and firm levels, with knowledge having to be shared with group members before individuals' knowledge is converted into common sense (Huber 1991; Tsai 2001). Because teams are both work divisions and important learning units (Decuyper et al. 2010; Senge 1997), team learning can help individuals deepen and share their thoughts, facilitate cooperation between teams, and support organizations' response towards the continuously changing environment (Decuyper et al. 2010; Sweet and Michaelsen 2007). However, although group learning can potentially improve collective knowledge and skills (Ellis et al. 2003), challenges will remain on how team members can deal with new tasks collaboratively and how teams can keep improving performance through learning in repeated operations (Edmondson et al. 2007).

\section{Heterogeneity in top management teams}

Evaluating different antecedents to strategic decisions made by TMTs is a major area of concern within the management literature (Wiersema and Bantel 1992). As the upper echelons perspective proposes, TMT characteristics can shape executives' perceptions, values, and attitudes, which then affect information-processing and decisionmaking behaviors and influence firms' outcomes (Hambrick and Mason 1984). Prior research has mainly analyzed two dimensions of TMT characteristics: homogeneity and heterogeneity (Carpenter et al. 2004; Hambrick and Mason 1984), with the former referring to an aggregate index of interpersonal similarity and the latter focusing on the degree of group diversity in demographic and cognitive features (Murray 1989; Simons et al. 1999). However, extant analyses are inconsistent when differentiating the composition of TMT heterogeneity, as some attempted to include age, tenure, functional background, and educational background (Hambrick et al. 1996), whereas others (e.g., Simons et al. 1999) advocated two types: more job-related (functional background, education level, and tenure) and less job-related (age) heterogeneity. Elsewhere, Nielsen (2010a) tried to convert multiple demographic measures into a single index of TMT heterogeneity, which however seems to be hard to measure. Because top executives' career backgrounds can significantly affect their cognitive structures, skills, and knowledge (Gunz and Jalland 1996), we have chosen TMT functional background and tenure to measure heterogeneity (Lee and Park 2006). Although many investigations, mainly based on the upper echelons perspective, have paid considerable attention to the effect 
of overall TMT heterogeneity on organizational performance such as strategic choices (Certo et al. 2006; Chaganti et al. 2016), they do not always lead to consistent outcomes (Roh et al. 2019). For example, some studies found that TMT heterogeneity could improve corporate innovation and growth (Boone and Hendriks 2009), but others demonstrated that TMT heterogeneity would either exert negative effects (Soulat and Nasir 2017) or have no significant impact (West, Jr and Schwenk 1996) on firm performance. Thus, the inner mechanism beneath paradoxical conclusions deserves further discussion.

It is this limited scope of research on TMT characteristics and firms' internationalization that has provided certain direction for future research. For example, Li (2018), based on the information-processing perspective, demonstrated that TMT tenure has an inverted Ushaped relationship with internationalization, while others found that a larger TMT size could encourage companies to implement a broad global strategic posture that can foster a global vision (Sanders and Carpenter 1998). Hence empirical support is not sufficient to clarify how the inner mechanism of TMT heterogeneity will steer the decision to invest overseas. This research gap is even more visible when looking at the extant upper echelons discussions that mainly examine the relationship between TMT diversity and firm performance (Carpenter et al. 2004), rather than individual dynamics and international expansion.

Addressing this significant research void appears to be particularly important for the development of upper echelons theory and practice, as the gap has also provided a certain scope to guide future research. Meanwhile, research on the specific impact path for TMTs has been emerging, concentrating on communications, knowledge diversity, relational conflict, and cohesion, aiming to attribute these outcomes to different reasons (Roh et al. 2019).

The TMT is the powerful decision-maker guiding firms' strategic options and determining the fate of the organization (Weiner and Mahoney 1981). TMT members are in a critical position to collect and manage information and knowledge resources required by strategic actions (Thompson 1967). TMTs may obtain new ideas and capture next-stage strategic blueprints by exploring and exploiting current knowledge. Facing a strategic dilemma in complex global environments, knowledge and learning are vital for TMTs to make reasonable strategic decisions (Gulanowski et al. 2018; Johanson and Vahlne 2009). Therefore, an empirical measurement of the diversity of senior executives' functional backgrounds and tenure characteristics, based on the perspectives of KBV and team learning, would lead to an enhanced understanding of how TMT diversity can influence firms' OFDI commitment.

\section{Hypotheses development}

\section{Functional background heterogeneity and OFDI commitment}

Functional background refers to the distribution of an individual's working history across different functional areas such as marketing, finance, and operations (Bunderson 2003). Generally speaking, TMT functional background diversity can improve knowledge acquisition and facilitate efficient team learning, helping obtain a profound understanding of internationalization and promote OFDI commitment. 
First, diversified functional background may broaden TMT members' knowledge through higher degrees of differentiation in professional backgrounds and working experience (Marcel 2009), which will optimize knowledge structures and decision-making patterns. As for the depth of knowledge, since individual top executives are experts in their respective fields (Hambrick and Mason 1984), functional diversity will help them achieve more in-depth knowledge acquisition through self-learning and interaction with other group members. TMT members would need to strengthen the understanding of their respective areas by means of interpersonal communications and knowledge exchange processes (Dhanaraj et al. 2004). In the case of knowledge breadth diversity, a wider range of functional backgrounds among TMT members could also diversify information and knowledge resources (Simons et al. 1999). Overall, TMTs with greater functional background heterogeneity can obtain mutual learning and benefit from better social networks that provide easier access to external information resources and promote the scale of knowledge (Mitchell et al. 2016). In other words, greater TMT functional background heterogeneity could help build a solid knowledge foundation for OFDI choices, which is essential for coping with international uncertainties (Liesch and Knight 1999).

Second, greater functional background heterogeneity will enable TMTs to conduct sufficient team learning as knowledge is the central element of the learning process (acquisition, integration, and exploitation of knowledge) (Cohen and Levinthal 1990). Existing knowledge, with both tacit and explicit dimensions, can be socialized through learning from each other (Brockmann and Anthony 2002), contributing to a common understanding about a firm's strategic orientation (Santos et al. 2016). Meanwhile, team discussions based on individuals' varied knowledge will likely lead to new findings (Khodakarami and Chan 2014), helping TMTs improve learning skills and obtain cross-country information with members' rich knowledge stocks (Casillas et al. 2015).

As a vital strategic choice for MNEs, OFDI is often regarded as a risk-taking behavior (Duanmu 2014). But the risk of investing in a complicated foreign environment may be mitigated if MNEs have sufficient knowledge and superior learning skills. Research has confirmed that learning and knowledge are central components supporting early and mature internationalization. Since internationalization is a recursive process, knowledge acquisition is needed for increasing the commitment to overseas activities (Casillas et al. 2015; Johanson and Vahlne 1990). Therefore, those TMT members with more comprehensive knowledge can better analyze international activities from a variety of angles and identify potential opportunities for global expansion (Athanassiou and Nigh 2000). Meanwhile, strong team learning skills can help TMTs learn more from previous experience, and then contributes to future OFDI decisions.

Based on the above discussions, given the great complexity that top executives are likely to face when making internationalization decisions, TMT members would benefit from having differentiated functional backgrounds, so that members can contribute to decision-making with a variety of understanding and considerations. Diversified knowledge can also prevent TMTs from short-sighted behaviors and help them solve nonstandard, uncertain, and non-routine problems in a complicated and dynamic foreign environment (Yang and Wang 2014). Moreover, team 
learning based on prior experience can also reduce uncertainty and create teamlevel consensus for subsequent international expansion.

Hypothesis 1: Functional background heterogeneity in TMTs is positively associated with firms' OFDI commitment.

\section{Tenure heterogeneity and OFDI commitment}

TMT tenure is defined as the number of years that a top manager has been appointed to an organization (Talke et al. 2010), with tenure homogeneity indicating the extent of sharing experiences with the TMT. It has been argued that tenure heterogeneity is significant for firms' innovation and internationalization (Jaw and Lin 2009); however, TMT tenure heterogeneity can also lead to conflicts among team members, impeding the process of knowledge acquisition and team learning, and subsequently deferring or hindering collective OFDI agreements. First, TMT members with high tenure heterogeneity will have different cognitions towards enterprise resource endowments, strategic orientation, and organizational goals, and this could lead to conflicts among TMT members and cause difficulties in reaching a consensus in decision-making (Amason 1996; Carpenter 2002). In contrast, TMT members with similar tenure are more likely to develop shared mental models that enable cognitive collaboration (Tyran and Gibson 2008), improving interpersonal communications and overall cohesion (Hambrick et al. 2015). On the other hand, considering the strong influence of Confucian culture on the organizational atmosphere in China ( Du 2015, 2016), Chinese firms have a residual "superior order" (seniority) and hierarchical atmosphere with high power distance. As Chow et al. (1999) found, a culture with a high power distance orientation means that managers are more sensitive to hierarchy and less likely to express doubts about the status quo, even in the case of internationalization decision-making. Hence, tenure heterogeneity in Chinese firms will likely discourage interpersonal communications during the decision-making process, hence hindering top managers from developing a strong commitment to venture abroad.

Second, conflicts caused by tenure heterogeneity will result in a lack of interpersonal connection and knowledge exchange among team members (Ndofor et al. 2015; Simons et al. 1999). TMT members with conflicts will have difficulties engaging in internal collaboration and mutual adjustment, hence decreasing new knowledge creation through smooth interactions (Nonaka 1994). With divergence and conflicts within TMTs threatening collaborative outcomes or shared knowledge, the efficiency and effectiveness of the collective learning process will be undermined (Hinsz et al. 1997). Given that conflicts could impede the process of knowledge transfer and team learning, TMTs will have trouble collecting and processing a variety of information and knowledge from the global environment (Sanders and Carpenter 1998).

To respond to an often turbulent overseas environment, organizations need to constantly revise knowledge stocks and perceive suitable investment opportunities (Korsgaard et al. 2016). Although sometimes top executives might discover a new investment opportunity by accident, conflicts caused by TMT tenure heterogeneity may hamper the cohesion and smooth communications among members, and subsequently obstruct the effective exchanges of key strategic information and delay the decisionmaking process (Amason and Sapienza 1997; Rao and Tilt 2016). Given the above 
arguments, when team members have emotional conflicts that might hinder both innovation and international market cooperation (Jaw and Lin 2009), TMT tenure heterogeneity is likely to impede firms' OFDI commitment.

Hypothesis 2: Tenure heterogeneity in TMTs is negatively associated with firms' OFDI commitment.

\section{Methods}

\section{Data and sample}

This study chose Chinese enterprises listed on the Shanghai and Shenzhen stock markets from 2008 to 2014 to investigate the relationship between heterogeneity in TMTs and OFDI commitment. China serves as an ideal research context to test the aforementioned hypotheses. First, China has become the third biggest country in the world in terms of OFDI flows (UNCTAD 2018). The prominence of China's OFDI has attracted considerable interest among international business scholars for assessing its antecedents, with the country in need of more experts to provide insights for firms embarking on international ventures in a competitive global market. Although extant research has evaluated China's OFDI from country-, industry- and firm-level perspectives such as top management compensation, we also need more knowledge about TMT heterogeneity which may provide broad information and diverse skills (Carpenter 2002), while potentially generating conflicts among team members (Amason and Sapienza 1997). Second, the mean values of functional background and tenure heterogeneity are 0.721 and 0.647, exhibiting the salient diversity in China's top management team. Hence, China represents an appropriate lens through which we are able to examine the relationship between the heterogeneity in TMTs and OFDI commitment.

We obtained the data through the following steps. We began by searching the OFDI dataset from the Ministry of Commerce of the People's Republic of China that provides names of parent and subsidiary firms, OFDI year, and OFDI destinations. Compared with most previous datasets used in the extant literature, this source offers more comprehensive information about Chinese OFDI projects (Xia et al. 2014). Then we used the Chinese Research Data Services Platform to get basic information about listed companies, including firms' full names and founding dates. The platform also provides information of TMT tenure characteristics, which can be used to partly quantify the level of heterogeneity. The next step was to collect the functional background and foreign experience information of TMT members through the China Stock Market \& Accounting Research Database (CSMAR) (Lu et al. 2014). We also obtained financial data from the CSMAR database for potential factors that may affect OFDI commitment, including leverages and ownership structures. Finally, we gathered overseas sales revenue data of listed companies from the WIND database, as supplements to capture firm-level international experience.

We then removed these firms' investments in Hong Kong, Macao, and Taiwan and also overseas investments in tax havens such as the Cayman Islands, Bermuda, and the British Virgin Islands for taxation issues. We also ruled out those enterprises that do not have information about executive characteristics and any with abnormal values. After careful screening and verification, we obtained a total of 2636 sample firms from 15,160 observations between 2008 and 2014. 


\section{OFDI commitment}

OFDI commitment refers to the willingness to devote considerable effort to overseas investments. We measured OFDI commitment in three dimensions: OFDI propensity, OFDI intensity, and institutional distance of OFDI (Deng et al. 2018; Xia et al. 2014). OFDI propensity is measured by a dummy variable (OFDI dummy), which equals to 1 if the enterprise undertakes OFDI in a certain year and 0 otherwise. Given that a specific company may conduct multiple outward investment activities in one year, we employed variable OFDI project number to count the number of OFDI activities (Hu and Cui 2014; Xia et al. 2014).

The institutional environment is a vital factor for enterprises from emerging markets to make investment decisions (Luo and Tung 2007). The term institutional distance, developed by Kostova (1999), refers to the extent of dissimilarity between host and home institutional profiles that can lead to challenges and uncertainties to establish legitimacy in host countries (Kostova 1999; Kostova and Zaheer 1999; Xu and Shenkar 2002). Therefore, we used OFDI institutional distance as an indicator for the differentiated resources committed to OFDI in different locations, with the Index of Economic Freedom being the proxy (Miller et al. 2010). We calculated OFDI institutional distance as the difference in index scores between China and the host countries (Meyer et al. 2009). However, an enterprise may go to several host countries in a specific observation year, so we used average distance between China and all target countries.

\section{Heterogeneity in TMTs}

Extant studies have defined TMT differently. Some defined TMT as those executives who report directly to the Chief Executive Officer (CEO) (Boeker 1997). Others employed a broad definition of TMT, including executives above vice president and any insider directors (Li 2018; Michel and Hambrick 1992). Because there is a considerable overlap between board members and top executives in Chinese listed companies, we adopted the construct of "Supra TMT" that embodies both top executives and board members (Finkelstein and Hambrick 1996). The term also included firms' CEOs, Presidents, Senior Vice-Presidents, Executive Vice-Presidents, Chief Operating Officers, Chief Technology Officers, Chief Financial Officers and other top executives who are listed in annual reports. In this study, two dimensions, tenure and functional background, were chosen as the typical characteristics of TMT members.

To capture the disparity of distribution in TMTs, we used the coefficient of variation $(\mathrm{CV})$, defined as the standard deviation divided by the mean, to measure the tenure heterogeneity in TMT members. According to Allison (1978), CV is a scale invariant measure which is sensitive to relative rather than absolute differences. It provides a comparable measure of diversity in different attributes. Because of these desirable properties for examining unequal distribution (Wiersema and Bantel 1992), CV has been widely used as a diversity index in the literature (Williams and O'Reilly III 1998).

The functional background of TMT members is an indicator of an individual's working experience, knowledge stock and learning capacity. The diversity of functional background within a TMT represents differences in knowledge, skills, information, and experience (Biemann and Kearney 2010; Harrison and Klein 2007). Here we used Blau's (1977) 
index which is the most commonly used measure to capture such qualitative distinctions (Harrison and Klein 2007).

To measure the functional background heterogeneity in TMTs, we use the classification method from the CSMAR database and divide the functional background into 10 categories: production (4.57\%), ${ }^{1}$ research and development (8.90\%), design (1.18\%), human resources $(2.26 \%)$, management $(43.30 \%)$, marketing $(8.39 \%)$, finance $(9.89 \%)$, accounting (14.08\%), law (2.97\%), and other or unclear (4.47\%). We also found TMTs normally possess $7(28.66 \%)$ or $8(26.77 \%)$ types of functional background in a certain year. Then we adopted Blau's (1977) index to measure this variable:

$$
\text { Blau }=1-\sum_{i=1}^{n} P_{i}^{2}
$$

where $P_{i}$ is the percentage of TMT members in the $i$ th category of functional background, and the value of Blau is between 0 and 1. The higher the resulting score is, the greater the TMT's heterogeneity will be (Carpenter 2002).

\section{Control variables}

In order to eliminate the potential factors that may disturb the measurement of OFDI commitment, we control for firm-level variables (including firm size, firm age, ownership structure, and financial leverage), team-level variables and industry-specific variables. We adopted the natural logarithm of total assets in RMB (Chinese currency) to measure firm size, which is of great significance for strategic decisions, as larger firms are more likely to go abroad due to easier access to market information (Kumar 2008). Firm age is measured by the number of years since the firm was founded, as many studies seem to support the view that older firms are more inert than younger ones (Boeker 1997). Meanwhile, ownership structure plays a vital role in OFDI because foreign investors regard Chinese firms they have invested in as strategic localization bases (Wang et al. 2012). Since state-owned enterprises can obtain sufficient support from the government to invest overseas, and escape from an unsupportive business environment is a stronger motivation for private enterprises to make similar commitments (Ramasamy et al. 2012), foreign share and state share are defined as the equity share of foreign investors and of the government. Furthermore, given the trust and extended limitation placed by creditors, low-leverage companies can have more investment opportunities than high-leverage companies (Zou and Adams 2008). Therefore, financial leverage and operating leverage are also controlled in this study.

Firms' international expansion is a progressive and dynamic course, of which international experience (IE) plays a vital role and at different stages MNEs evolve by increasing their international presence and accumulating IE (Tihanyi et al. 2000). IE obtained from operations in overseas markets can provide valuable guidance for the next step of internationalization. Moreover, since top managers with IE may understand the institutions, quality standards, and expectations of international markets (Banerjee et al. 2015) and are in better positions to judge the risks and returns of international investments (Herrmann and Datta 2005), the IE of top executives might be an important determinant for internationalization involvement. Thus, we controlled for IE

\footnotetext{
${ }^{1}$ The figures in brackets represent the proportion of top executives in the specific category in the overall sample.
} 
at both the firm-level and the team-level. At the firm level, we used the percentage of overseas business revenue in prime operation revenue as the proxy for accumulated IE. And TMT IE is measured by the proportion of TMT members who have international education background or international working experience.

Moreover, we controlled the team-level variables including the number of TMT members, size of the board, and proportion of independent directors. Due to diverse motivations of OFDI in different industries, we set industry dummy variables to control industry-specific variations: 1 = finance; 2 =utility; 3 =real estate; 4 =comprehensive; 5 = industry; 6 = business. We included year dummy variables to control for cyclical disturbances.

\section{Statistical models}

Given the characteristics of dependent variables, we employed different regression models to test the hypotheses. To cater for the dichotomous outcome variable (OFDI dummy), we adopted a Probit model to examine the relationship between TMT heterogeneity and OFDI propensity. We also employed the Tobit model, as the dependent variables such as OFDI project number and OFDI institutional distance are left censored. Considering the two dependent variables that have a substantial number of zero observations, ordinary least square (OLS) regression would lead to biased and negative fitted values (Wooldridge 2015). To avoid severe estimation bias, a maximum likelihood estimator (MLE) of nonlinear Tobit models is applied in our study (Amemiya 1973). We lagged all independent variables by one year to alleviate possible endogeneity with the dependent variables, as well as controlling for cluster on each firm to account for unobserved firm-specific heterogeneity. ${ }^{2}$ We can specify the models as follows:

$$
\begin{aligned}
& P(\text { OFDI dummy }=1)=\alpha_{1}+\alpha_{2} \times \text { heterogeneity in } T M T+\beta_{1} \times \text { control }_{1} \\
& +\varepsilon_{1}, Y^{*}=\lambda_{1}+\lambda_{2} \times \text { heterogeneity in } T M T+\beta_{2} \times \text { control }_{2} \\
& +\varepsilon_{2}, Y=\max \left(0, Y^{*}\right),
\end{aligned}
$$

where $Y$ denotes OFDI project number/institutional distance and $Y^{*}$ is a latent variable.

\section{Empirical findings}

\section{Baseline results}

Table 1 shows the descriptive statistics and a correlation matrix for all the variables, with the correlation coefficients of all independent variables being less than 0.45 (maximum $=0.441$ ). Additionally, the variance inflation factors (VIF) among the variables are less than 2, indicating that multi-collinearity is not a great concern in our study (Sun et al. 2016). The mean value of OFDI propensity implies a relatively low level of overseas investment commitment. The mean heterogeneity of functional background in TMTs is above 0.6, which demonstrates diverse characteristics among TMT members. The average size of the sample companies is 21.793 and the total assets are approximately RMB 2914 million (equivalent to USD 420 million), which means our samples of listed firms, being large scaled enterprises, can provide a broad set of objects for the present study.

\footnotetext{
${ }^{2}$ The table can be provided upon request.
} 


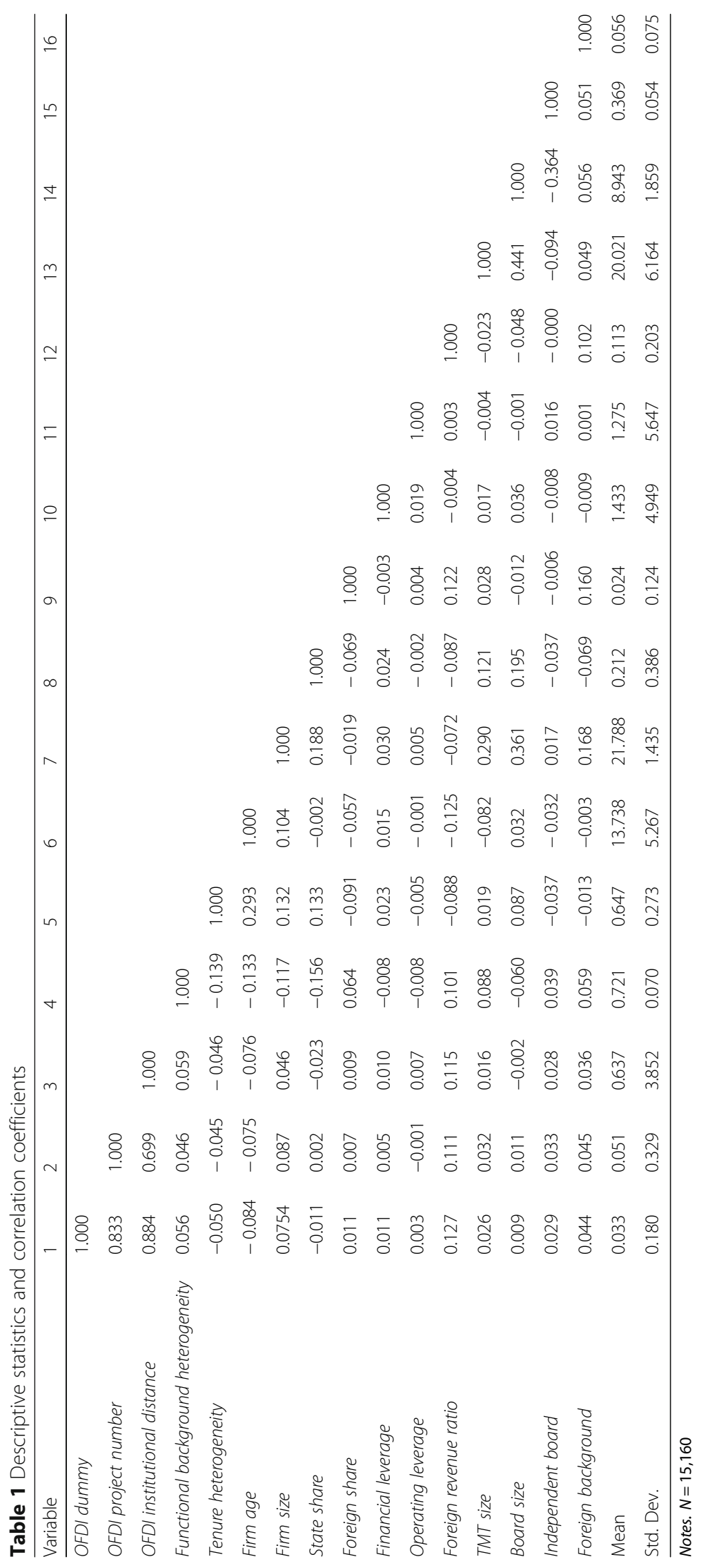


Table 2 presents the main empirical findings of the utilized Probit (Models 1-3) and Tobit (Models 4-9) regression models. All models appear to be statistically significant, supporting $\mathrm{H} 1$ and $\mathrm{H} 2$. The coefficient of functional background heterogeneity in Model 1 is $1.749(p<0.01)$, showing significant influence on the OFDI dummy. Following previous research ( $\mathrm{Hu}$ and Cui 2014), we use the number of OFDI projects as an alternative measure of overseas investment commitment. Subsequently, a significantly

Table 2 Effects of TMT heterogeneity on OFDI commitments

\begin{tabular}{|c|c|c|c|c|c|c|c|c|c|}
\hline \multirow[t]{2}{*}{ Variable } & \multicolumn{3}{|c|}{ OFDI dummy } & \multicolumn{3}{|c|}{ OFDI project number } & \multicolumn{3}{|c|}{ OFDI institutional distance } \\
\hline & Model 1 & Model 2 & Model 3 & Model 4 & Model 5 & Model 6 & Model 7 & Model 8 & Model 9 \\
\hline \multirow{2}{*}{$\begin{array}{l}\text { Functional } \\
\text { background } \\
\text { heterogeneity }\end{array}$} & $1.749^{c}$ & & $1.607^{c}$ & $4.359^{c}$ & & $4.007^{c}$ & $55.909^{c}$ & & $51.409^{c}$ \\
\hline & $(0.582)$ & & $(0.577)$ & $(1.431)$ & & $(1.417)$ & (18.374) & & $(18.215)$ \\
\hline \multirow{2}{*}{$\begin{array}{l}\text { Tenure } \\
\text { heterogeneity }\end{array}$} & & $-0.502^{c}$ & $-0.476^{c}$ & & $-1.222^{c}$ & $-1.157^{c}$ & & $-15.537^{c}$ & $-14.682^{c}$ \\
\hline & & $(0.137)$ & $(0.136)$ & & $(0.333)$ & $(0.332)$ & & $(4.295)$ & $(4.282)$ \\
\hline \multirow[t]{2}{*}{ Firm age } & $-0.068^{c}$ & $-0.062^{c}$ & $-0.059^{c}$ & $-0.167^{c}$ & $-0.153^{c}$ & $-0.146^{\mathrm{C}}$ & $-2.093^{c}$ & $-1.918^{c}$ & $-1.824^{c}$ \\
\hline & $(0.008)$ & $(0.008)$ & $(0.008)$ & $(0.020)$ & $(0.020)$ & $(0.020)$ & $(0.256)$ & $(0.261)$ & $(0.260)$ \\
\hline \multirow[t]{2}{*}{ Firm size } & $0.225^{c}$ & $0.224^{c}$ & $0.237^{c}$ & $0.572^{c}$ & $0.567^{c}$ & $0.601^{c}$ & $6.733^{c}$ & $6.675^{c}$ & $7.105^{c}$ \\
\hline & $(0.032)$ & $(0.031)$ & $(0.032)$ & $(0.079)$ & $(0.078)$ & $(0.079)$ & $(1.013)$ & $(1.004)$ & $(1.018)$ \\
\hline \multirow[t]{2}{*}{ State share } & $-0.171^{\mathrm{a}}$ & $-0.164^{\mathrm{a}}$ & -0.156 & $-0.443^{\mathrm{a}}$ & $-0.425^{a}$ & $-0.405^{\mathrm{a}}$ & $-7.144^{b}$ & $-6.935^{b}$ & $-6.674^{b}$ \\
\hline & $(0.098)$ & $(0.098)$ & $(0.098)$ & $(0.240)$ & $(0.240)$ & $(0.240)$ & (3.124) & (3.125) & (3.125) \\
\hline \multirow[t]{2}{*}{ Foreign share } & -0.331 & -0.348 & -0.375 & -0.709 & -0.746 & -0.813 & -10.477 & -10.892 & -11.786 \\
\hline & $(0.263)$ & $(0.261)$ & $(0.261)$ & $(0.636)$ & $(0.632)$ & $(0.632)$ & (8.253) & (8.204) & $(8.205)$ \\
\hline \multirow{2}{*}{$\begin{array}{l}\text { Financial } \\
\text { leverage }\end{array}$} & 0.001 & 0.001 & 0.001 & 0.001 & 0.001 & 0.000 & 0.041 & 0.049 & 0.061 \\
\hline & $(0.007)$ & $(0.007)$ & $(0.007)$ & $(0.015)$ & $(0.016)$ & $(0.016)$ & $(0.204)$ & $(0.209)$ & $(0.209)$ \\
\hline \multirow{2}{*}{$\begin{array}{l}\text { Operating } \\
\text { leverage }\end{array}$} & 0.002 & 0.001 & 0.002 & 0.005 & 0.003 & 0.004 & 0.074 & 0.054 & 0.065 \\
\hline & $(0.007)$ & $(0.006)$ & $(0.007)$ & $(0.016)$ & $(0.016)$ & $(0.016)$ & $(0.220)$ & $(0.216)$ & $(0.222)$ \\
\hline \multirow{2}{*}{$\begin{array}{l}\text { Foreign } \\
\text { revenue ratio }\end{array}$} & $1.308^{c}$ & $1.306^{c}$ & $1.291^{c}$ & $3.207^{c}$ & $3.202^{c}$ & $3.168^{c}$ & $40.726^{c}$ & $40.690^{c}$ & $40.236^{c}$ \\
\hline & $(0.148)$ & $(0.148)$ & $(0.147)$ & $(0.375)$ & $(0.374)$ & $(0.372)$ & $(4.817)$ & $(4.811)$ & $(4.786)$ \\
\hline \multirow[t]{2}{*}{ TMT size } & 0.007 & 0.008 & 0.006 & 0.018 & 0.020 & 0.016 & 0.217 & 0.251 & 0.198 \\
\hline & $(0.005)$ & $(0.005)$ & $(0.005)$ & $(0.012)$ & $(0.012)$ & $(0.012)$ & $(0.159)$ & $(0.157)$ & $(0.158)$ \\
\hline \multirow[t]{2}{*}{ Board size } & 0.008 & 0.008 & 0.008 & 0.017 & 0.015 & 0.017 & 0.267 & 0.248 & 0.276 \\
\hline & $(0.023)$ & $(0.023)$ & $(0.023)$ & $(0.056)$ & $(0.056)$ & $(0.056)$ & $(0.725)$ & $(0.723)$ & $(0.722)$ \\
\hline \multirow{2}{*}{$\begin{array}{l}\text { Independent } \\
\text { board }\end{array}$} & 0.072 & 0.091 & 0.025 & 0.142 & 0.208 & 0.034 & 2.753 & 3.763 & 1.455 \\
\hline & $(0.666)$ & $(0.663)$ & $(0.663)$ & $(1.620)$ & $(1.610)$ & $(1.612)$ & (20.843) & (20.738) & (20.752) \\
\hline \multirow{2}{*}{$\begin{array}{l}\text { Foreign } \\
\text { background }\end{array}$} & 0.126 & 0.201 & 0.132 & 0.360 & 0.544 & 0.370 & 2.697 & 5.000 & 2.797 \\
\hline & $(0.449)$ & $(0.447)$ & $(0.446)$ & $(1.091)$ & $(1.084)$ & $(1.084)$ & $(14.065)$ & (13.996) & (13.989) \\
\hline \multirow[t]{2}{*}{ Constant } & $-8.752^{c}$ & $-7.316^{c}$ & $-8.668^{c}$ & -37.453 & -34.077 & -37.203 & -469.739 & -431.232 & -461.457 \\
\hline & $(0.876)$ & $(0.709)$ & $(0.870)$ & (332.995) & (443.334) & (339.796) & $(6185.415)$ & $\begin{array}{l}(10, \\
865.22)\end{array}$ & (4615.238) \\
\hline $\begin{array}{l}\text { Industry } \\
\text { dummies }\end{array}$ & Yes & Yes & Yes & Yes & Yes & Yes & Yes & Yes & Yes \\
\hline $\begin{array}{l}\text { Year } \\
\text { dummies }\end{array}$ & Yes & Yes & Yes & Yes & Yes & Yes & Yes & Yes & Yes \\
\hline $\begin{array}{l}\text { Log } \\
\text { likelihood }\end{array}$ & $\begin{array}{l}- \\
1599.030\end{array}$ & $\begin{array}{l}- \\
1596.759\end{array}$ & $\begin{array}{l}- \\
1592.692\end{array}$ & - & - & $\begin{array}{l}- \\
2184.593\end{array}$ & $\begin{array}{l}- \\
3308.483\end{array}$ & - & $\begin{array}{l}- \\
3302.320\end{array}$ \\
\hline Wald $c h i^{2}$ & $231.29^{c}$ & $233.74^{c}$ & $238.91^{c}$ & $200.93^{c}$ & $202.91^{c}$ & $206.40^{c}$ & $185.70^{c}$ & $187.21^{c}$ & $190.61^{c}$ \\
\hline
\end{tabular}


positive relationship between functional background heterogeneity and OFDI project numbers is shown in Model 4. Model 7 depicts the positive effect of functional background heterogeneity on OFDI institutional distance, thereby strongly supporting H1.

$\mathrm{H} 2$ suggests that the tenure heterogeneity is negatively associated with firms' OFDI commitment. As shown in Table 2, the effect of tenure heterogeneity on OFDI commitment is negative and significant (see Models 2, 5 and 8), which provides strong support for H2. This result is also consistent with previous studies stating that the tenure heterogeneity could generate conflicts in an organization (Murray 1989). To further confirm the explanatory power of the model we constructed, we reported the results of full models with the inclusion of both heterogeneity variables in the regressions (Models 3, 6 and 9), which are consistent with our hypotheses.

Table 2 also shows that the control variables exhibit salient different influences on OFDI commitment. Firm age and state share have similarly negative effects on firm internationalization, whereas firm size positively influences OFDI commitment. Firm age reflects the degree of its accumulation in intellectual abilities and experience (Wei et al. 2014). It demonstrates that the growth of firm age can enable the company to gain a more advantageous position and more profits in the home market, thereby weakening the motivation and enthusiasm to expand to the less familiar global environment. While state share reflects the impacts of the partly control of company shares by the national government on strategic decisions such as OFDI. Meanwhile, the expansion of firm size has enabled companies to obtain more OFDI-related resources and capabilities, and subsequently enhance firms' ability to internationalize their businesses (Shao and Shang 2016).

When it comes to the international experience, the degree of IE differs between the firm-level and the team-level. The coefficient of foreign business revenue is significantly positive, while the foreign background presents no remarkable effects on OFDI commitment. Benefiting from the accumulated international operation experience, firms may become more familiar with international business and more easily absorb useful information on host countries (Wei et al. 2014). As a consequence, this learning and experimentation can lead them to expand OFDI. The non-significant effect of foreign background within TMTs on OFDI may have something to do with the governance situation in Chinese listed firms. The overall mean of foreign background in the sample is only $5.4 \%$, which means the top managers with international backgrounds do not gain strong discourse rights in the whole group.

\section{Robustness tests}

We conducted sets of tests to ensure the robustness of our findings. First, the Heckman two-stage regression is deployed to mitigate potential endogeneity problem. To implement OFDI, some firms may choose to hire top executives with diverse backgrounds and set up a heterogenous TMT before embarking on OFDI several years earlier. Thus, the sample selection bias and reverse causality will challenge the validity of empirical results. Following the guidelines provided by Dastidar (2009) and Kim et al. (2015), we employed a two-stage Heckman estimation procedure, with the first stage (selection model) addressing probability of overseas expansion and the second stage (effects model) addressing OFDI commitment. In the first stage, we investigated the probability 
of OFDI by including firm size, TMT size, board size, independent board, state share, foreign share, financial leverage, operating leverage, foreign background ratio, and foreign revenue ratio as well as post-listing duration. Although we used a time-lag structure for the dependent variables, we also took the post-listing duration as the instrumental variable in the first-stage Heckman selection equation to deal with reverse causality (Bascle 2008; Kim et al. 2015). ${ }^{3}$ We obtained inverse mills ratio (IMR) from the first stage, which is included in the second stage regression models along with control and independent variables (see Table 3). By so doing we are able to find that the coefficient of IMR is not statistically significant in all the regression models, indicating that our previous estimation does not suffer from severe sample selection. The results in Table 3 reveal the significant effect of TMT heterogeneity on OFDI commitment, consistent with baseline results.

Second, we adopted an alternative measure for independent variables. There has been research that investigates the "scope of internationalization" by examining geographical dispersion (e.g., Goerzen and Beamish 2003; Jiménez et al. 2014). Following the extant literature, we used the number of foreign countries that have subsidies of Chinese MNEs to capture the scope of internationalization, as country-count measures are considered relatively accurate when addressing scope issues (García-García et al. 2017). The empirical results consistently support $\mathrm{H} 1$ and $\mathrm{H} 2$ (Table 4).

Third, we modify the tenure heterogeneity by means of standard deviation (SD). Although CV is a universal diversity index, it would trigger invisible bias in specific domains. For example, suppose the teams had equal separation on age, and SDs of age were the same $(\mathrm{SD}=10)$ in Team $\mathrm{A}$ and Team $\mathrm{B}$. But in Team $\mathrm{A}$ the mean level of age was 20 and in Team B it was 40 . When an investigator uses CV as an operationalization of within-unit separation, he/she would mistakenly conclude that Team A $(C V=0.5)$ had twice the separation as Team B $(C V=0.25)$. Therefore, we exercise SD, the most important measures of diversity as separation (Biemann and Kearney 2010), to measure the tenure heterogeneity. The outcomes of this robustness test are still in line with H1 (Table 5).

Fourth, we use alternative measures for functional background heterogeneity based on entropy. The computational formula for Teachman's (1980) index originally developed by Shannon (1948) is defined as:

$$
T I=-\sum_{i=1}^{n}\left[P_{i} \times \operatorname{Ln}\left(P_{i}\right)\right]
$$

where $P_{i}$ is the proportion of group members in the $i$ th category. As group members are spreading more evenly and across a richer number of categories, Teachman's index rises. Due to the desirable mathematical properties, this index has been shown to be part of a general class of diversity or information richness measures (Harrison and Klein 2007). The empirical results still support our assumptions (Table 6).

\footnotetext{
${ }^{3}$ The post-listing duration refers to the time since listing as a public company. To satisfy the public and investors, listed companies have to improve their governance structure and construct TMTs with diverse members. While publicly listed firms could gain access to capital and some other resources, the post-listing duration has no direct correlation with outward investment which needs to consider numerous factors. Thereby, the post-listing duration is a desirable instrumental variable for our study.
} 
Table 3 Results of the second-stage Heckman regression analysis

\begin{tabular}{|c|c|c|c|c|c|c|}
\hline \multirow[t]{2}{*}{ Variable } & \multicolumn{2}{|c|}{ OFDI dummy } & \multicolumn{2}{|c|}{ OFDI project number } & \multicolumn{2}{|c|}{ OFDI institutional distance } \\
\hline & Model 1 & Model 2 & Model 3 & Model 4 & Model 5 & Model 6 \\
\hline \multirow[t]{2}{*}{ Functional background heterogeneity } & $0.084^{c}$ & & $0.144^{\mathrm{b}}$ & & $1.784^{c}$ & \\
\hline & $(0.025)$ & & $(0.044)$ & & $(0.528)$ & \\
\hline \multirow[t]{2}{*}{ Tenure heterogeneity } & & $-0.031^{c}$ & & $-0.055^{c}$ & & $-0.524^{c}$ \\
\hline & & $(0.007)$ & & $(0.017)$ & & $(0.148)$ \\
\hline \multirow[t]{2}{*}{ Firm age } & $-0.003^{c}$ & $-0.003^{c}$ & $-0.006^{c}$ & $-0.005^{c}$ & $-0.061^{c}$ & $-0.056^{c}$ \\
\hline & $(0.000)$ & $(0.000)$ & $(0.001)$ & $(0.001)$ & $(0.007)$ & $(0.009)$ \\
\hline \multirow[t]{2}{*}{ Firm size } & $0.012^{c}$ & $0.011^{c}$ & $0.022^{c}$ & $0.021^{c}$ & $0.169^{c}$ & $0.164^{c}$ \\
\hline & $(0.001)$ & $(0.001)$ & $(0.003)$ & $(0.004)$ & $(0.031)$ & $(0.033)$ \\
\hline \multirow[t]{2}{*}{ State share } & -0.003 & -0.004 & 0.002 & 0.001 & $-0.202^{b}$ & $-0.206^{b}$ \\
\hline & $(0.005)$ & $(0.005)$ & $(0.008)$ & $(0.011)$ & $(0.098)$ & $(0.099)$ \\
\hline \multirow[t]{2}{*}{ Foreign share } & $-0.024^{a}$ & $-0.026^{a}$ & -0.029 & -0.032 & -0.458 & $-0.500^{\mathrm{a}}$ \\
\hline & $(0.013)$ & $(0.014)$ & $(0.024)$ & $(0.032)$ & $(0.289)$ & $(0.290)$ \\
\hline \multirow[t]{2}{*}{ Financial leverage } & -0.000 & -0.000 & -0.001 & -0.001 & -0.004 & -0.004 \\
\hline & $(0.000)$ & $(0.000)$ & $(0.001)$ & $(0.001)$ & $(0.008)$ & $(0.008)$ \\
\hline \multirow[t]{2}{*}{ Operating leverage } & 0.000 & 0.000 & 0.000 & 0.000 & 0.003 & 0.002 \\
\hline & $(0.000)$ & $(0.000)$ & $(0.000)$ & $(0.001)$ & $(0.006)$ & $(0.006)$ \\
\hline \multirow[t]{2}{*}{ Foreign revenue ratio } & $0.100^{c}$ & $0.099^{c}$ & $0.161^{c}$ & $0.159^{c}$ & $1.887^{\mathrm{c}}$ & $1.885^{c}$ \\
\hline & $(0.009)$ & $(0.009)$ & $(0.015)$ & $(0.021)$ & $(0.183)$ & $(0.182)$ \\
\hline \multirow[t]{2}{*}{ TMT size } & $0.001^{b}$ & $0.001^{c}$ & $0.001^{b}$ & $0.002^{b}$ & $0.012^{a}$ & $0.015^{b}$ \\
\hline & $(0.000)$ & $(0.000)$ & $(0.001)$ & $(0.001)$ & $(0.007)$ & $(0.007)$ \\
\hline \multirow[t]{2}{*}{ Board size } & -0.000 & -0.001 & -0.002 & -0.002 & -0.011 & -0.011 \\
\hline & $(0.001)$ & $(0.001)$ & $(0.002)$ & $(0.003)$ & $(0.024)$ & $(0.025)$ \\
\hline \multirow[t]{2}{*}{ Independent board } & 0.025 & 0.023 & 0.080 & 0.069 & 0.442 & 0.465 \\
\hline & $(0.034)$ & $(0.035)$ & $(0.061)$ & $(0.081)$ & $(0.725)$ & $(0.717)$ \\
\hline \multirow[t]{2}{*}{ Foreign background } & 0.037 & 0.036 & $0.089^{b}$ & 0.082 & 0.695 & 0.771 \\
\hline & $(0.023)$ & $(0.025)$ & $(0.042)$ & $(0.058)$ & $(0.495)$ & $(0.510)$ \\
\hline \multirow[t]{2}{*}{ Constant } & $-0.352^{c}$ & $-0.254^{c}$ & $-0.682^{c}$ & $-0.504^{c}$ & $-5.536^{\mathrm{c}}$ & $-3.984^{c}$ \\
\hline & $(0.045)$ & $(0.049)$ & $(0.081)$ & $(0.115)$ & $(0.961)$ & $(1.016)$ \\
\hline \multirow[t]{2}{*}{ Inverse Mill's ratio } & 0.055 & -0.191 & -0.070 & -0.446 & 0.717 & -0.007 \\
\hline & $(0.251)$ & $(0.217)$ & $(0.453)$ & $(0.507)$ & (5.392) & $(4.508)$ \\
\hline Industry dummies & Yes & Yes & Yes & Yes & Yes & Yes \\
\hline Year dummies & Yes & Yes & Yes & Yes & Yes & Yes \\
\hline Wald $c h i^{2}$ & $472.55^{c}$ & $442.56^{c}$ & $463.30^{c}$ & $261.36^{\mathrm{C}}$ & $345.31^{c}$ & $337.32^{c}$ \\
\hline
\end{tabular}

Notes. Standard errors are in parentheses. ${ }^{\mathrm{a}}, \mathrm{b}, \mathrm{c}$ denote statistical significance at the $10 \%, 5 \%, 1 \%$ levels respectively (two-tailed tests)

\section{Discussion}

Previous studies on outward investments from emerging markets mainly focused on the country-level, industry-level, and firm-level antecedents, whereas the team-level factors (such as TMT) are under-explored. Although scholars have noticed the role of board structure and top-executive compensation on OFDI, the effect of heterogeneity in TMTs remains under-studied. To address this gap, this study employs KBV and team learning to explore how heterogeneity in TMTs affects OFDI commitment. We proposed that the functional background heterogeneity would benefit efficient team learning and 
Table 4 Effects of TMT heterogeneity on scope of internationalization

\begin{tabular}{|c|c|c|c|}
\hline \multirow[t]{2}{*}{ Variable } & \multicolumn{3}{|c|}{ Scope of internationalization } \\
\hline & Model 1 & Model 2 & Model 3 \\
\hline \multirow[t]{2}{*}{ Functional background heterogeneity } & $3.532^{c}$ & & $3.237^{c}$ \\
\hline & $(1.214)$ & & $(1.203)$ \\
\hline \multirow[t]{2}{*}{ Tenure heterogeneity } & & $-1.036^{c}$ & $-0.985^{c}$ \\
\hline & & $(0.283)$ & $(0.282)$ \\
\hline \multirow[t]{2}{*}{ Firm age } & $-0.143^{c}$ & $-0.131^{c}$ & $-0.125^{c}$ \\
\hline & $(0.017)$ & $(0.017)$ & $(0.017)$ \\
\hline \multirow[t]{2}{*}{ Firm size } & $0.478^{c}$ & $0.473^{c}$ & $0.501^{c}$ \\
\hline & $(0.067)$ & $(0.066)$ & $(0.067)$ \\
\hline \multirow[t]{2}{*}{ State share } & $-0.372^{\mathrm{a}}$ & $-0.358^{\mathrm{a}}$ & $-0.341^{\mathrm{a}}$ \\
\hline & $(0.203)$ & $(0.203)$ & $(0.203)$ \\
\hline \multirow[t]{2}{*}{ Foreign share } & -0.614 & -0.648 & -0.703 \\
\hline & $(0.542)$ & $(0.538)$ & $(0.539)$ \\
\hline \multirow[t]{2}{*}{ Financial leverage } & 0.001 & 0.002 & 0.002 \\
\hline & $(0.013)$ & $(0.014)$ & $(0.014)$ \\
\hline \multirow[t]{2}{*}{ Operating leverage } & 0.004 & 0.002 & 0.003 \\
\hline & $(0.013)$ & $(0.013)$ & $(0.014)$ \\
\hline \multirow[t]{2}{*}{ Foreign revenue ratio } & $2.751^{c}$ & $2.744^{c}$ & $2.719^{c}$ \\
\hline & $(0.320)$ & $(0.319)$ & $(0.317)$ \\
\hline \multirow[t]{2}{*}{ TMT size } & 0.015 & 0.017 & 0.014 \\
\hline & $(0.010)$ & $(0.010)$ & $(0.010)$ \\
\hline \multirow[t]{2}{*}{ Board size } & 0.016 & 0.020 & 0.021 \\
\hline & $(0.046)$ & $(0.046)$ & $(0.046)$ \\
\hline \multirow[t]{2}{*}{ Independent board } & 0.032 & 0.138 & -0.014 \\
\hline & $(1.333)$ & $(1.324)$ & $(1.327)$ \\
\hline \multirow[t]{2}{*}{ Foreign background } & 0.217 & 0.370 & 0.229 \\
\hline & $(0.933)$ & $(0.927$ & $(0.928)$ \\
\hline \multirow[t]{2}{*}{ Constant } & -31.052 & -28.455 & $-30.927^{c}$ \\
\hline & (208.729) & $(302.606)$ & $(222.436)$ \\
\hline Industry dummies & Yes & Yes & Yes \\
\hline Year dummies & Yes & Yes & Yes \\
\hline Log likelihood & -2119.557 & -2117.004 & -2113.180 \\
\hline Wald $c h i^{2}$ & $196.40^{c}$ & $198.80^{c}$ & $201.84^{c}$ \\
\hline
\end{tabular}

Notes. Standard errors are in parentheses. ${ }^{a, b}, c$ denote statistical significance at the $10 \%$ and $1 \%$ level respectively

accumulative knowledge acquisition. Considering the conflicts brought about by tenure diversity, we also proposed that such heterogeneity would hinder the transfer of knowledge and the team learning process, hence weakening OFDI commitment. Our results support the hypotheses, as the findings on the relationship between tenure heterogeneity and OFDI commitment correspond to pertinent evidence of internationalization. A similar pattern was reported by Ancona and Caldwell (1992) who studied 409 individuals from 45 new product teams in five high-technology companies, as they found that high levels of tenure diversity could impede performance because of the resultant lower level of capability for teamwork. Given that extant research has mainly investigated two categories of the learning activities in relation to internationalization, namely individual learning and 


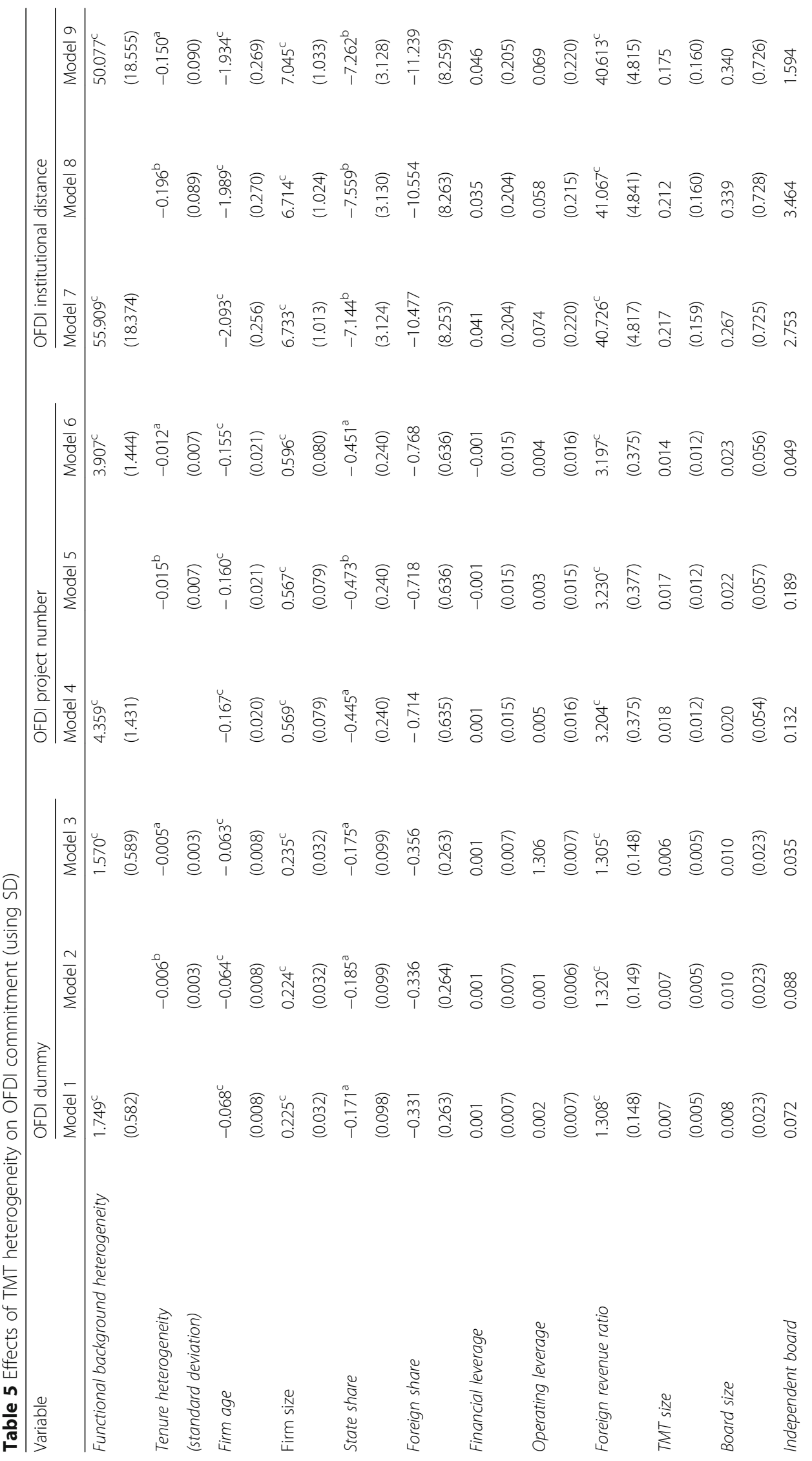




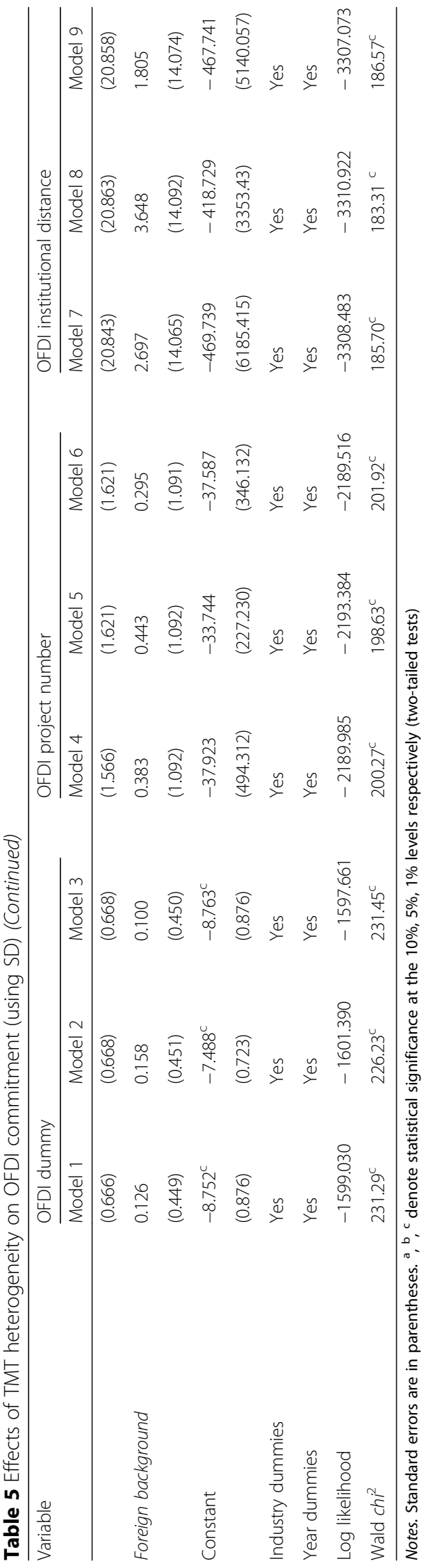




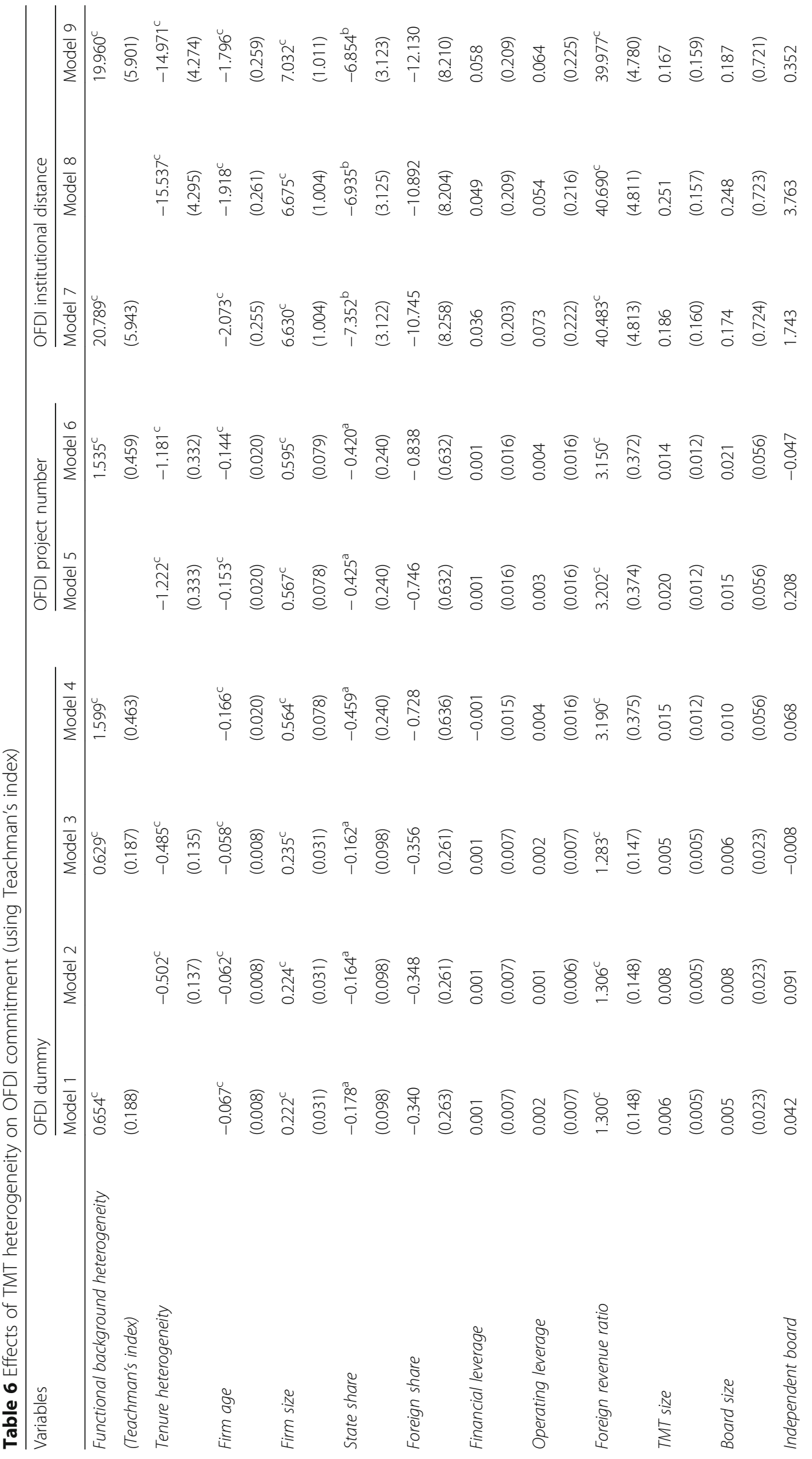




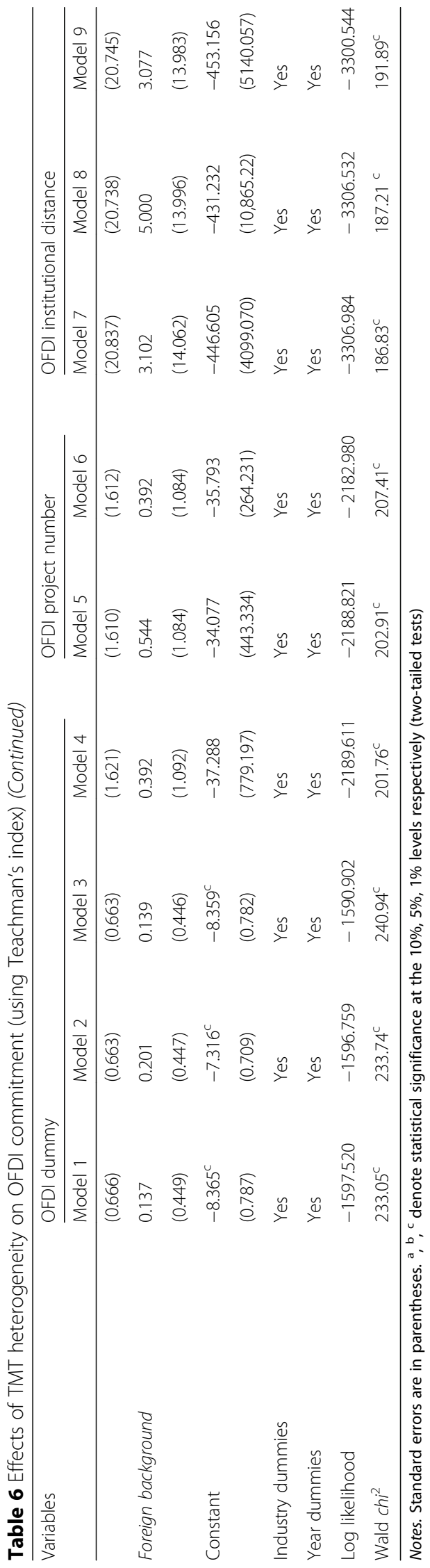


organizational learning (e.g., Johanson and Vahlne 2003; Jones and Coviello 2005), our focus on TMT team learning will take the discussion on this topic a step forward.

This study enriches the growing literature on TMT heterogeneity and the internationalization of emerging market economy firms. Our findings advance the understanding of how the composition of TMT members can influence Chinese firms' decisions to venture internationally, an important appreciation given the rising prominence of emerging economies in global FDI output. By incorporating the diversity characteristics of TMTs, we differentiated TMT tenure and functional background heterogeneity that have various effects on OFDI, which deepens the understanding of the dynamics of OFDI and TMT governance. TMT heterogeneity, as the study discovers, does not only form multiple layers of knowledge and perception, but also generates conflicts among TMT members and influences the strategic decision-making on international expansion (Carpenter and Fredrickson 2001). Our results imply that since the composition and structure of TMTs have crucial effects on MNEs, paying particular attention to different roles inside TMT heterogeneity is a step forward for further investigating the key factors influencing the process of internationalization.

A further contribution of this research is that the evaluation of TMT heterogeneity is assisted by the use of the KBV, a framework that has not been adequately used in this area. Drawing on this perspective enables us to provide new insights into TMT heterogeneity by identifying the different roles within TMT heterogeneity. It has also led to more dynamic findings that demonstrate the negative effects of tenure heterogeneity and positive effects of functional heterogeneity on OFDI commitments. Contrary to most previous research that focused on the optimistic impact of overall heterogeneity on firms' internationalization processes, our study suggests that these conventional investigations might have neglected the adverse effect of specific dimensions of heterogeneity. This can be illustrated by a new term we have proposed, "the multiplicity of TMT heterogeneity," as it is essential to distinguish different dimensions of TMT heterogeneity leading to different effects on strategic decisions such as OFDI.

This study also provides some additional insights into the utilization of learning theories in internationalization research by highlighting the effect of team learning on firms' TMT and OFDI, while most extant research has either captured organizational learning processes and outcomes as a whole (e.g., Barkema and Vermeulen 1998; Fernández-Mesa and Alegre 2015), or ascribed great importance to individual learning, particularly the knowledge or international experience of entrepreneurs and managers (e.g.). Our approach to focusing on team learning, on the contrary, offers a renewed analytical perspective linking knowledge acquisition, international experience and firms' OFDI commitment.

The results of this research have certain implications for emerging economy firms that are seeking opportunities of overseas investment. This paper finds that, whilst other antecedents are also important, the differentiation of TMT members plays an extremely vital role in making strategic choices that will influence international expansion. Therefore, it is important for these firms to maximize the benefits of TMT diversity and mitigate its drawbacks. For companies from emerging markets that try to achieve successful OFDI, building a normative corporate governance system and diversifying the TMT structure will have profound impacts on companies' internationalization. This implies that firms should select and appoint senior executives 
who have diversified functional backgrounds and generally consistent tenure length, so as to broaden the knowledge base and information source of their TMTs and promote efficient communications between members.

Despite the contributions, our research has several limitations that need to be addressed in future research. First, due to time and data constraints, this study only considers two dimensions (functional background and tenure) when capturing the heterogeneity dynamics of TMTs. Further research is needed to extend the investigation to other sub-paths of TMT characteristics and explore the TMT heterogeneity impact by considering the contextual elements within a more comprehensive and systematic system. Second, our current focus is restricted to the general mode of outward international direct investment, which may neglect the differences in OFDI entry modes such as greenfield projects, acquisitions, or joint ventures. Different OFDI entry modes require various information resource bases and show diverse risk-taking levels (Meyer et al. 2009). Thus, future research is awaited providing a further examination of the relationship between TMT heterogeneity and the firm's commitment to a variety of OFDI entry modes. Third, due to data availability, we only analyzed Chinese listed firms, and non-listed companies are not included in this study. Methodologically, an improvement of the research design in future research, for instance comparing findings based on non-listed companies in the field of enquiry, would help offset this weakness. Fourth, although we have tried the Heckman two-stage model to mitigate the potential endogeneity issue, the persistence of this issue means that the instrumental variables deserve further consideration. Finally, this research is carried out in the Chinese context and the findings are influenced by the unique institutional environment within which the sample firms are located. Incorporating firms from other economies would help increase the generalization of the research outcome. It will be very interesting to see whether future research can broaden the scope and extend the applicability of the findings to other emerging markets.

\section{Conclusion}

This study adds to the TMT heterogeneity research with an attentive proposition, and enriches the upper echelons literature by highlighting the important, yet complex impact of the two underexplored TMT dimensions, functional background and tenure, on Chinese firms' OFDI decisions. Our empirical results support the hypotheses that the functional background diversity has a positive correlation with these firms' OFDI commitment, while the impact of tenure heterogeneity is negative. These findings imply that the internationalization of emerging market firms can be affected differently by various dimensions of TMT characteristics. The results advance our understanding of the relationship between TMT heterogeneity and firm decision-making, and suggest the future research directions in this important field. Potentially, associating firms' different modes of OFDI with the multiple characteristics of TMTs may enhance our understanding about the underlying internationalization directions chosen by firms from emerging economies. 


\section{Acknowledgements}

We appreciate the comments from Professor Ziliang Deng, the Symposium on Strategic Management and International Business (Beijing, China) organized by Frontiers of Business Research in China and the three reviewers on earlier versions of this paper.

\section{About the authors'}

Shuai Meng is a Ph.D. candidate in international business at the Business School, Renmin University of China, Beijing. His research has focused on TMT and global expansion.

Jiayan Yan (corresponding author), is Assiatant Professor at School of Business, Nanjing Audit University. She obtained Ph.D. from Renmin University of China and was a visiting Ph.D. student at the Darla Moore School of Business, University of South Carolina (September 2017-June 2018). Her research has focused on outward foreign direct investment from China, and her recent papers have been published in International Business Review and Journal of Business Ethics.

Xuebing Cao is Assiatant Professor of HRM at Keele Management School, Keele University, UK. His reserach interest has focused on entrepreneurship, leadership, international strategic HRM, the emerging trade unionism and labour movement in China. He has published papers in journals such as Globalizations, Frontiers of Business Research in China and Industrial Relations Journal. He is a member of editorial board of The International Journal of Human Resource Management and Asia Pacific Journal of Human Resources.

\section{Authors' contributions}

SM joined the research design, undertook the empirical analysis, and drafted the manuscript. JY conceived the study, designed the research, and helped to draft the manuscript. XB participated in the correction of the manuscript and also provided the guidance to use the most appropriate theoretical analysis. All authors read and approved the final manuscript.

\section{Funding}

Not applicable.

\section{Availability of data and materials}

1 OFDI dataset (http://project.mofcom.gov.cn/1800000091_10000108_8.html). Information about names of parent and subsidiary firms, OFDI year, and OFDI destinations.

2 Chinese Research Data Services Platform (https:/www.cnrds.com/Home/Login). Data to build the tenure heterogeneity variable and obtain basic information of listed companies.

3 CSMAR database (http://www.gtarsc.com/). Information to build the functional background heterogeneity variable and obtain financial data of listed companies.

4 WIND database (https://www.wind.com.cn/). Data about foreign sales revenue of listed companies.

\section{Ethics approval and consent to participate}

We certify that this manuscript is original and has not been published and will not be submitted elsewhere for publication while being considered by editors. And the study is not split up into several parts to increase the quantity of submissions and submitted to various journals or to one journal over time. No data have been fabricated or manipulated to support our conclusions. No data, text, or theories by others are presented as if they were our own. The submission has been received explicitly from all co-authors. And authors whose names appear on the submission have contributed sufficiently to the scientific work and therefore share collective responsibility and accountability for the results.

\section{Consent for publication}

Not applicable.

\section{Competing interests}

The authors declare that they have no competing interests.

\section{Author details}

${ }^{1}$ Business School, Renmin University of China, Beijing 100872, China. ${ }^{2}$ School of Business, Nanjing Audit University, Nanjing 211815, China. ${ }^{3}$ Keele Management School, Keele University, Staffordshire ST5 5BG, UK.

Received: 1 January 2019 Accepted: 23 July 2019

Published online: 26 September 2019

\section{References}

Allison, P. D. (1978). Measures of inequality. American Sociological Review, 43(6), 865-880.

Amason, A. C. (1996). Distinguishing the effects of functional and dysfunctional conflict on strategic decision making: Resolving a paradox for top management teams. Academy of Management Journal, 39(1), 123-148.

Amason, A. C., \& Sapienza, H. J. (1997). The effects of top management team size and interaction norms on cognitive and affective conflict. Journal of Management, 23(4), 495-516.

Amemiya, T. (1973). Regression analysis when the dependent variable is truncated normal. Econometrica, 41(6), 997-1016.

Anand, G., Ward, P. T., \& Tatikonda, M. V. (2010). Role of explicit and tacit knowledge in six sigma projects: An empirical examination of differential project success. Journal of Operations Management, 28(4), 303-315.

Ancona, D. G., \& Caldwell, D. F. (1992). Demography and design: Predictors of new product team performance. Organization Science, 3(3), 321-341. 
Athanassiou, N., \& Nigh, D. (2000). Internationalization, tacit knowledge and the top management teams of MNCs. Journal of International Business Studies, 31(3), 471-487.

Banerjee, S., Prabhu, J. C., \& Chandy, R. K. (2015). Indirect learning: How emerging-market firms grow in developed markets. Journal of Marketing, 79(1), 10-28.

Barkema, H. G., \& Vermeulen, F. (1998). International expansion through start-up or acquisition: A learning perspective. Academy of Management Journal, 41(1), 7-26.

Barney, J. (1991). Firm resources and sustained competitive advantage. Journal of Management, 17(1), 99-120.

Bascle, G. (2008). Controlling for endogeneity with instrumental variables in strategic management research. Strategic Organization, 6(3), 285-327.

Biemann, T., \& Kearney, E. (2010). Size does matter: How varying group sizes in a sample affect the most common measures of group diversity. Organizational Research Methods, 13(3), 582-599.

Blau, P. M. (1977). Inequality and heterogeneity: A primitive theory of social structure. New York: Free Press.

Blome, C., Schoenherr, T., \& Eckstein, D. (2014). The impact of knowledge transfer and complexity on supply chain flexibility: A knowledge-based view. International Journal of Production Economics, 147, 307-316.

Boeker, W. (1997). Strategic change: The influence of managerial characteristics and organizational growth. Academy of Management Journal, 40(1), 152-170.

Boone, C., \& Hendriks, W. (2009). Top management team diversity and firm performance: Moderators of functionalbackground and locus-of-control diversity. Management Science, 55(2), 165-180.

Brockmann, E. N., \& Anthony, W. P. (2002). Tacit knowledge and strategic decision making. Group \& Organization Management, 27(4), 436-455.

Bunderson, J. S. (2003). Team member functional background and involvement in management teams: Direct effects and the moderating role of power centralization. Academy of Management Journal, 46(4), 458-474.

Bunderson, J. S., \& Sutcliffe, K. A. (2003). Management team learning orientation and business unit performance. Journal of Applied Psychology, 88(3), 552-560.

Carpenter, M. A. (2002). The implications of strategy and social context for the relationship between top management team heterogeneity and firm performance. Strategic Management Journal, 23(3), 275-284.

Carpenter, M. A., \& Fredrickson, J. W. (2001). Top management teams, global strategic posture, and the moderating role of uncertainty. Academy of Management Journal, 44(3), 533-545.

Carpenter, M. A., Geletkanycz, M. A., \& Sanders, W. G. (2004). Upper echelons research revisited: Antecedents, elements, and consequences of top management team composition. Journal of Management, 30(6), 749-778.

Casillas, B., Barbero, J. L., \& Sapienza, H. J. (2015). Knowledge acquisition, learning, and the initial pace of internationalization. International Business Review, 24(1), 102-114.

Casillas, M., Moreno, A. M., Acedo, F. J., Gallego, M. A., \& Ramos, E. (2009). An integrative model of the role of knowledge in the internationalization process. Journal of World Business, 44(3), 311-322.

Certo, S. T., Lester, R. H., Dalton, C. M., \& Dalton, D. R. (2006). Top management teams, strategy and financial performance: A meta-analytic examination. Journal of Management Studies, 43(4), 813-839.

Chaganti, R. S., Zimmerman, M. A., Kumaraswamy, A., Maggitti, P., \& Arkles, J. B. (2016). TMT characteristics, time-to-IPO and firm performance. Journal of Management and Public Policy, 7(2), 37.

Chow, C. W., Harrison, G. L., McKinnon, J. L., \& Wu, A. (1999). Cultural influences on informal information sharing in Chinese and Anglo-American organizations: An exploratory study. Accounting, Organizations and Society, 24(7), 561-582.

de Clercq, D., Sapienza, H. J., Yavuz, R. I., \& Zhou, L. (2012). Learning and knowledge in early internalization research: Past accomplishments and future directions. Journal of Business Venturing, 27(1), 143-165.

Cohen, W. M., \& Levinthal, D. A. (1990). Absorptive capacity: A new perspective on learning and innovation. Administrative Science Quarterly, 35(1), 128-152.

Crossan, M. M., Lane, H. W. \& White, R. E. (1999). An organizational learning framework: From intuition to institution. Academy of Management Review, 24(3), 522-537.

Dastidar, P. (2009). International corporate diversification and performance: Does firm self-selection matter? Journal of International Business Studies, 40(1), 71-85.

Decuyper, S., Dochy, F., \& van den Bossche, P. (2010). Grasping the dynamic complexity of team learning: An integrative model for effective team learning in organisations. Educational Research Review, 5(2), 111-133.

Deng, Z., Yan, J., \& van Essen, M. (2018). Heterogeneity of political connections and outward foreign direct investment. International Business Review, 27(4), 893-903.

Dhanaraj, C., Lyles, M. A., Steensma, H. K., \& Tihanyi, L. (2004). Managing tacit and explicit knowledge transfer in IJVs: The role of relational embeddedness and the impact on performance. Journal of International Business Studies, $35(5), 428-442$.

Du, X. (2015). Does Confucianism reduce minority shareholder expropriation? Evidence from China. Journal of Business Ethics, 132(4), 661-716.

Du, X. (2016). Does Confucianism reduce board gender diversity? Firm-level evidence from China. Journal of Business Ethics, 136(2), 399-436

Duanmu, J.L. (2014). State-owned MNCs and host country expropriation risk: The role of home state soft power and economic gunboat diplomacy. Journal of International Business Studies, 45(8), 1044-1060.

Duffield, S., \& Whitty, S. J. (2015). Developing a systemic lessons learned knowledge model for organisational learning through projects. International Journal of Project Management, 33(2), 311-324.

Easterby-Smith, M., \& Prieto, I. M. (2008). Dynamic capabilities and knowledge management: An integrative role for learning? British Journal of Management, 19(3), 235-249.

Edmondson, A. C., Dillon, J. R., \& Roloff, K. S. (2007). Three perspectives on team learning outcome improvement, task mastery, and group process. Academy of Management Annals, 1, 269-314.

Ellis, A. P., Hollenbeck, J. R., Ilgen, D. R., Porter, C. O., West, B. J., \& Moon, H. (2003). Team learning: Collectively connecting the dots. Journal of Applied Psychology, 88(5), 821.

Fernández-Mesa, A., \& Alegre, J. (2015). Entrepreneurial orientation and export intensity: Examining the interplay of organizational learning and innovation. International Business Review, 24(1), 148-156. 
Finkelstein, S., \& Hambrick, D. C. (1996). Strategic leadership: Top executives and their effects on organizations. St Paul: West Publishing.

García-García, R., Garcia-Canal, E., \& Guillen, M. F. (2017). Rapid internationalization and long-term performance: The knowledge link. Journal of World Business, 52(1), 97-110.

Gassmann, O., \& Keupp, M. M. (2007). The competitive advantage of early and rapidly internationalising SMEs in the biotechnology industry: A knowledge-based view. Journal of World Business, 42(3), 350-366.

Gaur, A. S., Kumar, V., \& Singh, D. (2014). Institutions, resources, and internationalization of emerging economy firms. Journal of World Business, 49(1), 12-20.

Goerzen, A., \& Beamish, P. W. (2003). Geographic scope and multinational enterprise performance. Strategic Management Journal, 24(13), 1289-1306.

Grant, R. M. (1996). Toward a knowledge-based theory of the firm. Strategic Management Journal, 17(S2), 109-122.

Gulanowski, D., Papadopoulos, N., \& Plante, L. (2018). The role of knowledge in international expansion: Toward an integration of competing models of internationalization. Review of International Business and Strategy, 28(1), 35-60.

Gunz, H. P., \& Jalland, R. M. (1996). Managerial careers and business strategies. Academy of Management Review, 21(3), 718-756.

Hambrick, D. C., Cho, T. S., \& Chen, M.J. (1996). The influence of top management team heterogeneity on firms' competitive moves. Administrative Science Quarterly, 41(4), 659-684.

Hambrick, D. C., Humphrey, S. E., \& Gupta, A. (2015). Structural interdependence within top management teams: A key moderator of upper echelons predictions. Strategic Management Journal, 36(3), 449-461.

Hambrick, D. C., \& Mason, P. A. (1984). Upper echelons: The organization as a reflection of its top managers. Academy of Management Review, 9(2), 193-206.

Harrison, D. A., \& Klein, K. J. (2007). What's the difference? Diversity constructs as separation, variety, or disparity in organizations. Academy of Management Review, 32(4), 1199-1228.

Herrmann, P., \& Datta, D. K. (2005). Relationships between top management team characteristics and international diversification: An empirical investigation. British Journal of Management, 16(1), 69-78.

Hinsz, V. B., Tindale, R. S., \& Vollrath, D. A. (1997). The emerging conceptualization of groups as information processors. Psychological Bulletin, 121(1), 43.

Hu, H. W., \& Cui, L. (2014). Outward foreign direct investment of publicly listed firms from China: A corporate governance perspective. International Business Review, 23(4), 750-760.

Huber, G. P. (1991). Organizational learning: The contributing processes and the literatures. Organization Science, 2(1), 88-115.

Jaw, Y.-L., \& Lin, W.-T. (2009). Corporate elite characteristics and firm's internationalization: CEO-level and TMT-level roles. The International Journal of Human Resource Management, 20(1), 220-233.

Jiménez, A., Luis-Rico, I., \& Benito-Osorio, D. (2014). The influence of political risk on the scope of internationalization of regulated companies: Insights from a Spanish sample. Journal of World Business, 49(3), 301-311.

Johanson, J., \& Vahlne, J.-E. (1990). The mechanism of internationalisation. International Marketing Review, 7(4), 11-24.

Johanson, J., \& Vahlne, J.E. (2003). Business relationship learning and commitment in the internationalization process. Journal of International Entrepreneurship, 1(1), 83-101.

Johanson, J., \& Vahlne, J.-E. (2009). The Uppsala internationalization process model revisited: From liability of foreignness to liability of outsidership. Journal of International Business Studies, 40(9), 1411-1431.

Jones, M. V., \& Coviello, N. E. (2005). Internationalisation: Conceptualising an entrepreneurial process of behaviour in time. Journal of International Business Studies, 36(3), 284-303.

Kaplan, S., Schenkel, A., von Krogh, G., \& Weber, C. (2001). Knowledge-based theories of the firm in strategic management: A review and extension. International Journal of Project Management, 25, 143-158.

Khodakarami, F., \& Chan, Y. E. (2014). Exploring the role of customer relationship management (CRM) systems in customer knowledge creation. Information \& Management, 51(1), 27-42.

Kim, H., Hoskisson, R. E., \& Lee, S.-H. (2015). Why strategic factor markets matter: "New" multinationals' geographic diversification and firm profitability. Strategic Management Journal, 36(4), 518-536.

Kogut, B., \& Zander, U. (1992). Knowledge of the firm, combinative capabilities, and the replication of technology. Organization Science, 3(3), 383-397.

Korsgaard, S., Berglund, H., Thrane, C., \& Blenker, P. (2016). A tale of two kirzners: Time, uncertainty, and the "nature" of opportunities. Entrepreneurship Theory and Practice, 40(4), 867-889.

Kostova, T. (1999). Transnational transfer of strategic organizational practices: A contextual perspective. Academy of Management Review, 24(2), 308-324.

Kostova, T., \& Zaheer, S. (1999). Organizational legitimacy under conditions of complexity: The case of the multinational enterprise. Academy of Management Review, 24(1), 64-81.

Kumar, N. (2008). Emerging MNCs: Trends, patterns, and determinants of outward FDI by Indian enterprises. In New dimensions of economic globalization: Surge of outward foreign direct investment from Asia (pp. 141-167).

Lam, A. (2000). Tacit knowledge, organizational learning and societal institutions: An integrated framework. Organization Studies, 21(3), 487-513.

Lee, H. U., \& Park, J. H. (2006). Top team diversity, internationalization and the mediating effect of international alliances. British Journal of Management, 17(3), 195-213.

Lejpras, A. (2015). Knowledge, location, and internationalization: Empirical evidence for manufacturing SMEs. Economics of Innovation and New Technology, 24(8), 734-754.

Li, P.-Y. (2018). Top management team characteristics and firm internationalization: The moderating role of the size of middle managers. International Business Review, 27(1), 125-138.

Liesch, P. W., \& Knight, G. A. (1999). Information internalization and hurdle rates in small and medium enterprise internationalization. Journal of International Business Studies, 30(2), 383-394.

Liu, L., Lu, J., \& Chizema, A. (2014). Top executive compensation, regional institutions and Chinese OFDI. Journal of World Business, 49(1), 143-155. 
Lu, J., Liu, X., \& Wang, H. (2011). Motives for outward FDI of Chinese private firms firm resources, industry dynamics, and government policies. Management and Organization Review, 7(2), 223-248.

Lu, J., Liu, X., Wright, M., \& Filatotchev, I. (2014). International experience and FDI location choices of Chinese firms: The moderating effects of home country government support and host country institutions. Journal of International Business Studies, 45(4), 428-449.

Luo, Y., \& Tung, R. L. (2007). International expansion of emerging market enterprises: A springboard perspective. Journal of International Business Studies, 38(4), 481-498.

Marcel, J. J. (2009). Why top management team characteristics matter when employing a chief operating officer: A strategic contingency perspective. Strategic Management Journal, 30(6), 647-658.

Meyer, K. E., Estrin, S., Bhaumik, S. K., \& Peng, M. W. (2009). Institutions, resources, and entry strategies in emerging economies. Strategic Management Journal, 30(1), 61-80.

Michel, J. G., \& Hambrick, D. C. (1992). Diversification posture and top management team characteristics. Academy of Management Journal, 35(1), 9-37.

Miller, T., Holmes, K. R., \& Feulner, E. J. (2010). 2010 index of economic freedom. The Heritage Foundation \& The Wall Street Journal: Washington D.C. \& New York.

Milliken, F. J., \& Martins, L. L. (1996). Searching for common threads: Understanding the multiple effects of diversity in organizational groups. Academy of Management Review, 21(2), 402-433.

Mitchell, R., Boyle, B., Nicholas, S., Maitland, E., \& Zhao, S. (2016). Boundary conditions of a curvilinear relationship between decision comprehensiveness and performance: The role of functional and national diversity. Journal of Business Research, 69(8), 2801-2811.

Murray, A. I. (1989). Top management group heterogeneity and firm performance. Strategic Management Journal, 10(S1), 125-141.

Ndofor, H. A., Sirmon, D. G., \& He, X. (2015). Utilizing the firm's resources: How TMT heterogeneity and resulting faultlines affect TMT tasks. Strategic Management Journal, 36(11), 1656-1674.

Nielsen, S. (2010a). Top management team diversity: A review of theories and methodologies. International Journal of Management Reviews, 12(3), 301-316

Nielsen, S. (2010b). Top management team internationalization and firm performance. Management International Review, 50(2), 185-206.

Nonaka, I. (1994). A dynamic theory of organizational knowledge creation. Organization Science, 5(1), 14-37.

Osterloh, M., \& Frey, B. S. (2000). Motivation, knowledge transfer, and organizational forms. Organization Science, 11(5), 538-550.

Pfeffer, J. (1985). Organizational demography-implications for management. California Management Review, 28(1), 67-81.

Pradhan, J. P. (2017). Indian outward FDI: A review of recent developments. Transnational Corporations, 24(2), 43-70

Ramasamy, B., Yeung, M., \& Laforet, S. (2012). China's outward foreign direct investment: Location choice and firm ownership. Journal of World Business, 47(1), 17-25.

Rao, K., \& Tilt, C. (2016). Board composition and corporate social responsibility: The role of diversity, gender, strategy and decision making. Journal of Business Ethics, 138(2), 327-347.

Roh, H., Chun, K., Ryou, Y., \& Son, J. (2019). Opening the black box: A meta-analytic examination of the effects of top management team diversity on emergent team processes and multilevel contextual influence. Group \& Organization Management, 44(1), 112-164.

Saarenketo, S., Puumalainen, K., Kuivalainen, O., \& Kyläheiko, K. (2004). Dynamic knowledge-related learning processes in internationalizing high-tech SMEs. International Journal of Production Economics, 89(3), 363-378.

Sanders, W. G., \& Carpenter, M. A. (1998). Internationalization and firm governance: The roles of CEO compensation, top team composition, and board structure. Academy of Management Journal, 41(2), 158-178.

Santos, C. M., Passos, A. M., \& Uitdewilligen, S. (2016). When shared cognition leads to closed minds: Temporal mental models, team learning, adaptation and performance. European Management Journal, 34(3), 258-268.

Schoenherr, T., Griffith, D. A., \& Chandra, A. (2014). Knowledge management in supply chains: The role of explicit and tacit knowledge. Journal of Business Logistics, 35(2), 121-135.

Senge, P. M. (1997). The fifth discipline. Measuring Business Excellence, 1(3), 46-51.

Shannon, C. E. (1948). A mathematical theory of communication. Bell System Technical Journal, 27(3), 379-423.

Shao, Y., \& Shang, Y. (2016). Decisions of OFDI engagement and location for heterogeneous multinational firms: Evidence from Chinese firms. Technological Forecasting and Social Change, 112, 178-187.

Simons, T., Pelled, L. H., \& Smith, K. A. (1999). Making use of difference: Diversity, debate, and decision comprehensiveness in top management teams. Academy of Management Journal, 42(6), 662-673.

Soulat, A., \& Nasir, N. (2017). Examining the role of employee diversity management and employee involvement variation on organizational innovation: A study from Pakistan. Singaporean Journal of Business, Economics and Management Studies, $51(118), 1-8$.

Stoian, C., \& Mohr, A. (2016). Outward foreign direct investment from emerging economies: Escaping home country regulative voids. International Business Review, 25(5), 1124-1135.

Sun, P., Hu, H. W., \& Hillman, A. J. (2016). The dark side of board political capital: Enabling blockholder rent appropriation. Academy of Management Journal, 59(5), 1801-1822.

Sweet, M., \& Michaelsen, L. K. (2007). How group dynamics research can inform the theory and practice of postsecondary small group learning. Educational Psychology Review, 19(1), 31-47.

Talke, K., Salomo, S., \& Rost, K. (2010). How top management team diversity affects innovativeness and performance via the strategic choice to focus on innovation fields. Research Policy, 39(7), 907-918.

Teachman, J. D. (1980). Analysis of population diversity: Measures of qualitative variation. Sociological Methods \& Research, $8(3), 341-362$

Thompson, J. D. (1967). Organizations in action: Social science bases of administrative theory. Social Science Electronic Publishing, 48(3), 498.

Tihanyi, L., Ellstrand, A. E., Daily, C. M., \& Dalton, D. R. (2000). Composition of the top management team and firm international diversification. Journal of Management, 26(6), 1157-1177.

Tsai, W. (2001). Knowledge transfer in intraorganizational networks: Effects of network position and absorptive capacity on business unit innovation and performance. Academy of Management Journal, 44(5), 996-1004. 
Tyran, K. L., \& Gibson, C. B. (2008). Is what you see, what you get? The relationship among surface-and deep-level heterogeneity characteristics, group efficacy, and team reputation. Group \& Organization Management, 33(1), 46-76.

UNCTAD. (2018). World investment report 2018: Investment and new industrial policies. New York and Geneva: United Nations.

Villar, C., Alegre, J., \& Pla-Barber, J. (2014). Exploring the role of knowledge management practices on exports: A dynamic capabilities view. International Business Review, 23(1), 38-44.

Wang, C., Hong, J., Kafouros, M., \& Wright, M. (2012). Exploring the role of government involvement in outward FDI from emerging economies. Journal of International Business Studies, 43(7), 655-676.

Wei, Y., Zheng, N., Liu, X., \& Lu, J. (2014). Expanding to outward foreign direct investment or not? A multi-dimensional analysis of entry mode transformation of Chinese private exporting firms. International Business Review, 23(2), 356-370.

Weiner, N., \& Mahoney, T. A. (1981). A model of corporate performance as a function of environmental, organizational, and leadership influences. Academy of Management Journal, 24(3), 453-470.

West, C. T., Jr., \& Schwenk, C. R. (1996). Top management team strategic consensus, demographic homogeneity and firm performance: A report of resounding nonfindings. Strategic Management Journal, 17(7), 571-576.

Wiersema, M. F., \& Bantel, K. A. (1992). Top management team demography and corporate strategic change. Academy of Management Journal, 35(1), 91-121.

Wiklund, J., \& Shepherd, D. (2003). Knowledge-based resources, entrepreneurial orientation, and the performance of small and medium-sized businesses. Strategic Management Journal, 24(13), 1307-1314.

Williams, K. Y., \& O'Reilly, C. A., III. (1998). Demography and diversity in organizations: A review of 40 years of research. Research in Organizational Behavior, 20, 77-140.

Wooldridge, J. M. (2015). Introductory econometrics: A modern approach. Toronto: Nelson education.

Xia, J., Ma, X., Lu, J. W., \& Yiu, D. W. (2014). Outward foreign direct investment by emerging market firms: A resource dependence logic. Strategic Management Journal, 35(9), 1343-1363.

Xu, D., \& Shenkar, O. (2002). Note: Institutional distance and the multinational enterprise. Academy of Management Review, 27(4), 608-618.

Yamakawa, Y., Peng, M. W., \& Deeds, D. L. (2008). What drives new ventures to internationalize from emerging to developed economies? Entrepreneurship Theory and Practice, 32(1), 59-82.

Yang, L., \& Wang, D. (2014). The impacts of top management team characteristics on entrepreneurial strategic orientation: The moderating effects of industrial environment and corporate ownership. Management Decision, 52(2), 378-409.

Zou, H., \& Adams, M. B. (2008). Corporate ownership, equity risk and returns in the People's Republic of China. Journal of International Business Studies, 39(7), 1149-1168.

\section{Publisher's Note}

Springer Nature remains neutral with regard to jurisdictional claims in published maps and institutional affiliations.

\section{Submit your manuscript to a SpringerOpen ${ }^{\circ}$ journal and benefit from:}

- Convenient online submission

- Rigorous peer review

- Open access: articles freely available online

High visibility within the field

- Retaining the copyright to your article

Submit your next manuscript at $\boldsymbol{\nabla}$ springeropen.com 